\title{
EFFECT OF THERMAL TREATMENT ON THE PHASE FORMATION AND ELECTRICAL PROPERTIES OF RICE HUSK SILICA BASED $\mathrm{Na}_{2} \mathrm{FeSiO}_{4}$ PRECURSORS
}

\author{
\#AGUS RIYANTO*, SUPRIHATIN*, SYAFRIADI*, SIMON SEMBIRING*, NOVITA SARI*, \\ ERASRI YUNI SUHESTI*, REZEKI SOFI KARIMAH*, RIFKI ALMUSAWI** \\ *Department of Physics, Faculty of Mathematics and Natural Sciences, Universitas Lampung, \\ Jl. Prof. Sumantri Brojonegoro No.1 Bandarlampung, 35145, Indonesia \\ **Department of Physics, Faculty of Mathematics and Natural Sciences, Universitas Indonesia, \\ Jl. Prof. Dr. Sudjono D Pusponegoro, Depok, 16424, Indonesia \\ "E-mail: agus.riyanto@fmipa.unila.ac.id
}

Submitted December 6, 2021; accepted January 14, 2022

\begin{abstract}
Keywords: Band gap, Electrical conductivity, $\mathrm{Na}_{2} \mathrm{FeSiO}_{4}$, Rice husk, Phase
This study aimed to explore the effect of thermal treatments on the phase composition and electrical properties of an $\mathrm{Na}_{2} \mathrm{FeSiO}_{4}$ precursor. Samples were prepared from $\mathrm{NaOH}, \mathrm{Fe}\left(\mathrm{NO}_{3}\right)_{3} \cdot 9 \mathrm{H}_{2} \mathrm{O}$, rice husk silica, and $\mathrm{C}_{6} \mathrm{H}_{8} \mathrm{O}_{7} \cdot \mathrm{H}_{2} \mathrm{O}$ using the sol-gel method. The samples were thermally treated at a temperature range of $350-475^{\circ} \mathrm{C}$ with a holding time of 10 hours. The functional groups of each sample were identified using Fourier transform infrared (FTIR) spectroscopy, and their phases were identified using $x$-ray diffraction (XRD) coupled with a qualitative and quantitative analysis. Meanwhile, the band gap and electrical conductivity of each sample were characterised using UV-Vis DRS and LCRmeter, respectively. The FTIR spectrum identified the functional groups of $\mathrm{Na}-\mathrm{O}, \mathrm{Fe}-\mathrm{O}$, and $\mathrm{Si}-\mathrm{O}$, which are associated with the tetrahedral structure of $\mathrm{NaO}_{4}, \mathrm{FeO}_{4}$, and $\mathrm{SiO}_{4}$. The XRD analysis reveals that the samples were dominated by $\mathrm{Na}_{2} \mathrm{FeSiO}_{4}$, followed by $\mathrm{FeSiO}_{3}$ and $\mathrm{SiO}_{2}$. The weight percent (wt. \%) and unit cell volume of the $\mathrm{Na}_{2} \mathrm{FeSiO}_{4}$ phase tend to increase with an increasing temperature and change in both influences of their band gap and electrical conductivity. The band gap value tends to decrease with an increasing temperature, inversely proportional to the wt. \% and unit cell volume, however, the electrical conductivity is opposite to their band gap value.
\end{abstract}

\section{INTRODUCTION}

Lithium-ion batteries have dominated the international market in energy storage for electronic device applications for many years [1]. This battery is composed of several components, including a cathode, an anode, an electrolyte, and a separator. The cathode plays a significant role in determining the specific capacity of the battery [2]. Orthosilicate materials are one of the favourites materials used for the cathode because they can accommodate energy in a high specific capacity [3]. For example, the orthosilicate material $\mathrm{Li}_{2} \mathrm{FeSiO}_{4}$ theoretically can save a specific capacity of about $330 \mathrm{mAh}^{-1}$ [4]. However, the increasing utilisation of lithium-ion batteries in various applications can be a problem because lithium raw materials are not abundant in nature. The limitations of lithium have caused the production cost of $\mathrm{Li}_{2} \mathrm{FeSiO}_{4}$ to be expensive. In addition, $\mathrm{Li}_{2} \mathrm{FeSiO}_{4}$ has low electrical conductivity. Liu et al. (2018) reported that the electrical conductivity of $\mathrm{Li}_{2} \mathrm{FeSiO}_{4}$ is in the order of $10^{-8}-10^{-14} \mathrm{Sm}^{-1}$, depending on the temperature [5]. This weakness prompted researchers to create a new orthosilicate compound with the formula $\mathrm{Na}_{2} \mathrm{FeSiO}_{4}$. The abundant availability of sodium in nature and the similar characteristics of sodium with lithium became the basic idea for making the compound [6]. This idea is also motivated by the fact that sodium and lithium almost have identical ionic, electronegativity, and electrochemical charges because they are in the same group in the periodic system [7-8].

The $\mathrm{Na}_{2} \mathrm{FeSiO}_{4}$ compound is constructed of $\mathrm{NaO}_{4}$, $\mathrm{FeO}_{4}$, and $\mathrm{SiO}_{4}$ tetrahedral anion units, and its structure can generally be viewed as a distorted hexagonal close packing network of oxygen ions whose half of the tetrahedral site are occupied by sodium, iron, or silicon [9]. All the atoms in the $\mathrm{Na}_{2} \mathrm{FeSiO}_{4}$ structure are covalently bonded. A robust covalent bond in the structure causes $\mathrm{Na}_{2} \mathrm{FeSiO}_{4}$ to have excellent chemical and structural stability, although it is classified as a polymorphic material [10]. The band gap value of $\mathrm{Na}_{2} \mathrm{FeSiO}_{4}$ is also relatively small, in a range of $1.23-2.51 \mathrm{eV}$, depending on the type of its polymorph structure [11]. It also has better electrical conductivity than the $\mathrm{Li}_{2} \mathrm{FeSiO}_{4}$ compound. Our previous study reported that the electrical conductivity of the $\mathrm{Na}_{2} \mathrm{FeSiO}_{4}$ compound is in the order of $10^{-5} \mathrm{~S} \cdot \mathrm{m}^{-1}[12]$. In addition, it theoretically 
can accommodate energy with a high specific capacity of around $278 \mathrm{mAh} \cdot \mathrm{g}^{-1}$, the approximate specific capacity of $\mathrm{Li}_{2} \mathrm{FeSiO}_{4}$ [13]. These properties make it possible for it to be potentially used as a new cathode candidate to replace $\mathrm{Li}_{2} \mathrm{FeSiO}_{4}$. The electrical conductivity plays a significant role in determining the properties of a battery cell, including its capacity and life cycle. A cathode material with an electrical conductivity of about $10^{-7}-10^{-2} \mathrm{~S} \cdot \mathrm{m}^{-1}$ is suitable enough for its use as a cathode in a battery system [14].

Many methods, such as the solvothermal method [15], sol-gel method [7, 16], and solid reaction method $[7,17]$, have been used to prepare $\mathrm{Na}_{2} \mathrm{FeSiO}_{4}$ compounds Kee et al. (2016) have successfully produced $\mathrm{Na}_{2} \mathrm{FeSiO}_{4}$ by using the solvothermal method [15]. They obtained a sample with the primary phase being $\mathrm{Na}_{2} \mathrm{FeSiO}_{4}$, but it is also accompanied by an impurity phase, such as $\mathrm{Na}_{2} \mathrm{SiO}_{3}$ and $\mathrm{Fe}_{3} \mathrm{O}_{4}$. The advantage of this method is that it can produce samples with a controlled particle size and structure, but the preparation process takes a long time. Meanwhile, Kaliyappan and Chen (2018) obtained $\mathrm{Na}_{2} \mathrm{FeSiO}_{4}$ by applying the solid state reaction method [17]. They obtained a sample with high crystallinity and purity, but a high temperature is required so that the reaction can occur in a short time. Previous studies reported that they have succeeded in producing the $\mathrm{Na}_{2} \mathrm{FeSiO}_{4}$ compound by applying the sol-gel method, but the second phase of $\mathrm{Na}_{2} \mathrm{SiO}_{3}$ is also present to accompany the primary phase $[6,18]$. This method can be operated at low temperatures and produces particles with relatively homogeneous morphology. All these methods have been proven to be applicable to produce $\mathrm{Na}_{2} \mathrm{FeSiO}_{4}$ regardless of the advantages and disadvantages.

Silica is one of the raw materials in the preparation of $\mathrm{Na}_{2} \mathrm{FeSiO}_{4}$ compounds. The need for silica to prepare this compound is generally supplied from tetraethyl orthosilicate (TOES) or fumed silica [6, 15, 17, 19]. The utilisation of silica from organic materials has become one of the trends in producing several silicabased materials to reduce production costs. Our previous study utilised rice husk silica to prepare $\mathrm{Na}_{2} \mathrm{FeSiO}_{4}$ compounds by applying the sol-gel method followed by thermal treatment at $800{ }^{\circ} \mathrm{C}$. We obtained a high crystalline $\mathrm{Na}_{2} \mathrm{FeSiO}_{4}$ phase, but slightly accompanied by other phases, namely $\mathrm{Na}_{2} \mathrm{SiO}_{3}$ and $\mathrm{SiO}_{2}$. This study shows that rice husk silica is potentially usable to prepare $\mathrm{Na}_{2} \mathrm{FeSiO}_{4}$ compounds [12]. Some of our previous studies also demonstrated the possibility of rice husk silica to produce silica-based materials, such as cordierite [20-22], forsterite [23-24], and geopolymers [25]. Our success in utilising amorphous silica from rice husks as the raw material is supported by the excellent rice husk silica properties, such as its high purity, amorphous level, and large surface area [26-28]. In addition, amorphous rice husk silica is easily dissolved in base solutions, even at room temperature, so that it readily reacts with other solutions [29].
In various studies, $\mathrm{Na}_{2} \mathrm{FeSiO}_{4}$ compounds have generally been prepared by thermal treatment methods at high temperatures of about $500{ }^{\circ} \mathrm{C}$ or greater $[16,30$ 31]. At this temperature, a $\mathrm{Na}_{2} \mathrm{FeSiO}_{4}$ phase is generally formed with high crystallinity, but several impurities are also present following the primary phase. Until now, no previous study reported the phase state equipped by the primary and impurity phase percentage from samples sintered at temperatures below $500{ }^{\circ} \mathrm{C}$. Therefore, this study reports the effect of the sintering temperature on the functional groups and phase of $\mathrm{Na}_{2} \mathrm{FeSiO}_{4}$ precursor samples sintered under $500{ }^{\circ} \mathrm{C}$. The samples were prepared according to our previous method, followed by thermal treatment at $350-475^{\circ} \mathrm{C}$ with a holding time of 10 hours at the peak temperature. This study also reports their band gap and electrical conductivity because these properties are essential in cathode development.

\section{EXPERIMENTAL}

The $\mathrm{Na}_{2} \mathrm{FeSiO}_{4}$ compound was prepared from materials consisting of dry and clean rice husk, $\mathrm{Fe}\left(\mathrm{NO}_{3}\right)_{3} \cdot 9 \mathrm{H}_{2} \mathrm{O} \quad 99 \%$ (Merck), $\quad \mathrm{NaOH} \quad 90 \quad \% \quad$ (Rp Chemical Product), and $\mathrm{C}_{6} \mathrm{H}_{8} \mathrm{O}_{7} \cdot \mathrm{H}_{2} \mathrm{O}$ (chelating agent).

\section{Extraction of the Amorphous Silica from the Rice Husk}

The amorphous silica powder was extracted from rice husk following the procedure in our previous study [12]. A total of $50 \mathrm{~g}$ of clean and dry rice husks were added to $500 \mathrm{ml}$ of a $\mathrm{NaOH} 5 \%$ solution and then heated for 30 minutes to form a sol. The sol was placed under atmospheric pressure at room temperature for 24 hours, then filtered to separate the sol from the remaining rice husks. The sol was added with a $\mathrm{HNO}_{3} 10 \%$ solution dropwise until a gel with a $\mathrm{pH}$ of 7 was obtained. The gel was washed using deionised water until clean, then dried at $110{ }^{\circ} \mathrm{C}$ to obtain a solid. The solid was ground using a mortar and pestle and then sieved using a 200-mesh sieve to obtain amorphous silica powder.

\section{$\mathrm{Na}_{2} \mathrm{FeSiO}_{4}$ Preparation}

$\mathrm{Na}_{2} \mathrm{FeSiO}_{4}$ was prepared using the sol-gel method following our previous study [12]. The samples were prepared from $\mathrm{NaOH}, \mathrm{Fe}\left(\mathrm{NO}_{3}\right)_{3} \cdot 9 \mathrm{H}_{2} \mathrm{O}$, amorphous silica powder from rice husks, and $\mathrm{C}_{6} \mathrm{H}_{8} \mathrm{O}_{7} \cdot \mathrm{H}_{2} \mathrm{O}$ with a mole ratio of $2: 1: 1: 1$. As much as $0.4 \mathrm{~g} \mathrm{NaOH}, 2.02 \mathrm{~g}$ $\mathrm{Fe}\left(\mathrm{NO}_{3}\right)_{3} \cdot 9 \mathrm{H}_{2} \mathrm{O}$, and $2 \mathrm{~g}$ of $\mathrm{C}_{6} \mathrm{H}_{8} \mathrm{O}_{7} \cdot \mathrm{H}_{2} \mathrm{O}$ were dissolved in $10 \mathrm{ml}, 25 \mathrm{ml}$, and $20 \mathrm{ml}$ of deionised water, respectively. As much as $0.3 \mathrm{~g}$ of $\mathrm{SiO}_{2}$ was put into a $\mathrm{NaOH}$ solution and then heated at $60{ }^{\circ} \mathrm{C}$ for 30 minutes under magnetic stirring to obtain a silica solution. The $\mathrm{Fe}\left(\mathrm{NO}_{3}\right)_{3} \cdot 9 \mathrm{H}_{2} \mathrm{O}$ 
solution was added to the silica solution, and then the $\mathrm{C}_{6} \mathrm{H}_{8} \mathrm{O}_{7} \cdot \mathrm{H}_{2} \mathrm{O}$ solution was added until the $\mathrm{pH}$ of the solution was 1 . The solution mixture was then put in a reflux system at $80^{\circ} \mathrm{C}$ for 5 hours under magnetic stirring until a yellowish solution was formed. The solution was then poured into a beaker and heated to $75{ }^{\circ} \mathrm{C}$ under magnetic stirring until the solvent evaporated and a gel was formed. The gel was then dried at $130{ }^{\circ} \mathrm{C}$ to form a solid. Furthermore, the solid was ground using a mortar and pastel to obtain a powder. The powder was thermally treated at a temperature of $350-475{ }^{\circ} \mathrm{C}$ with a heating rate of $3{ }^{\circ} \mathrm{C} \cdot \mathrm{min}^{-1}$ and held for 10 hours at the peak temperature. The sample was then ground and sieved using a 200-mesh sieve.

\section{Sample Characterisation}

Analysis was performed using Fourier transform infrared (FTIR) spectroscopy and X-Ray Diffraction (XRD) techniques to determine the functional groups and phases that formed in the sample. The functional groups of $\mathrm{Na}_{2} \mathrm{FeSiO}_{4}$ were analysed using a Nicolet iS10 FTIR in a wavenumber range of $4000-400 \mathrm{~cm}^{-1}$. The samples were prepared by grinding a mixture of the sample powder and $\mathrm{KBr}$ and then pressed into pellets. The data analysis was carried out by comparing the FTIR spectra with previous studies. The phases of the samples were characterised using X'Pert Powder PW 30/40 XRD on $\mathrm{Cu}-\mathrm{K} \alpha$ radiation operated at $40 \mathrm{kV}$ and $30 \mathrm{~mA}$. The step size used was $0.02^{\circ}$ per minute in a $2 \theta$ range from $10^{\circ}-100^{\circ}$. The qualitative phase analysis used the QualX software version 2.24 by applying the search-match method, namely comparing the experimental data with the database that had been installed [32]. Meanwhile, the quantitative analysis was performed on the Rietica program using the Rietveld method.

The band gap and electrical conductivity of the samples were analysed using a UV-Vis spectrophotometer

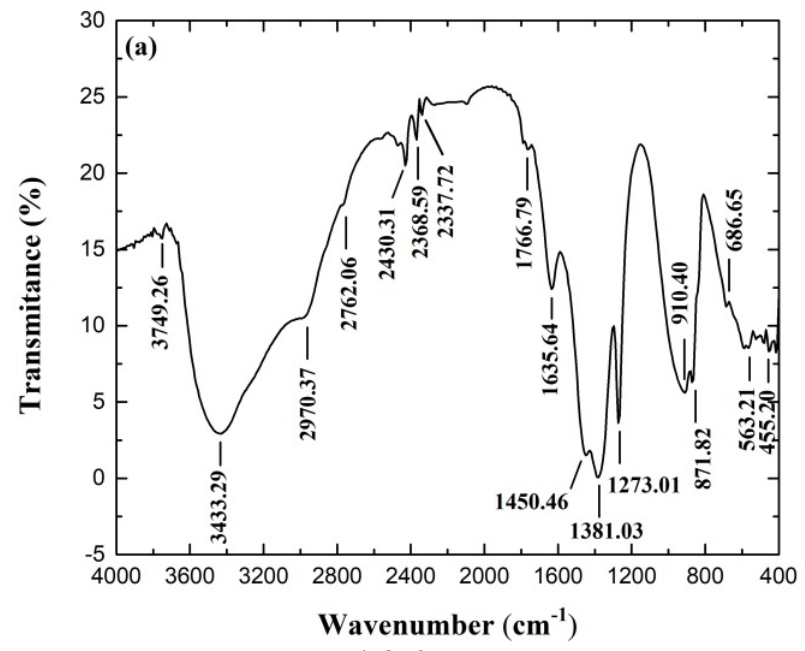

a) $350{ }^{\circ} \mathrm{C}$ and an LCRmeter. The samples were measured using a DRS Shimadzu UV-2450 UV-Vis spectrophotometer at a wavelength range of $200-800 \mathrm{~nm}$ to obtain the diffuse reflectance data to estimate the band gap. The diffuse reflectance data was processed using the Kubelka-Munk theorem and Tauc relation to predict the band gap value, namely

$$
F\left(R_{\infty}\right)=\frac{K}{S}=\frac{\left(1-R_{\infty}\right)^{2}}{2 R_{\infty}}
$$

and

$$
\left[F\left(R_{\infty}\right) h v\right]^{2}=A\left(h v-E_{g}\right)
$$

where $F\left(R_{\infty}\right)$ is the Kubelka-Munk function, $K$ is the absorption coefficient $\left(\mathrm{m}^{2} \cdot \mathrm{kg}^{-1}\right), S$ is the scattering coefficient $\left(\mathrm{m}^{2} \cdot \mathrm{kg}^{-1}\right), R_{\infty}$ is the diffuse reflection, $h$ is Planck constant $\left(6.6 \times 10^{-34} \mathrm{~m}^{2} \mathrm{~kg} \cdot \mathrm{s}^{-1}\right), A$ is proportionality constant $(\mathrm{J}), v$ is the frequency $(\mathrm{Hz})$, and $E_{g}$ is the band gap energy $(\mathrm{eV})$. Meanwhile, to analyse the electrical conductivity, $1.2 \mathrm{~g}$ of the sintered powder was compacted at a pressure of $78,400 \mathrm{KPa}$ to form a cylindrical pellet. The conductance of the samples was measured using an HIOKI 3520-52 LCRmeter in the frequency range of $50-60 \mathrm{~Hz}$. From the conductance data, the electrical conductivity of the sample was calculated using $\sigma=G \cdot(L / A)$, where $\sigma$ is the electrical conductivity $\left(\mathrm{S} \cdot \mathrm{m}^{-1}\right), L$ is the thickness of the sample (m), $G$ is the conductance ( $\mathrm{S}$ ), and $A$ is the cross-section of the sample surface $\left(\mathrm{m}^{2}\right)$.

\section{RESULTS AND DISCUSSION}

The functional groups in the sample were identified using FTIR, and their spectra are depicted in Figure 1a-f. The spectra indicate the presence of bonds related to the Na-O, Fe-O, and $\mathrm{Si}-\mathrm{O}$ groups of the $\mathrm{NaO}_{4}$, $\mathrm{FeO}_{4}$, and $\mathrm{SiO}_{4}$ tetrahedral structures that characterise

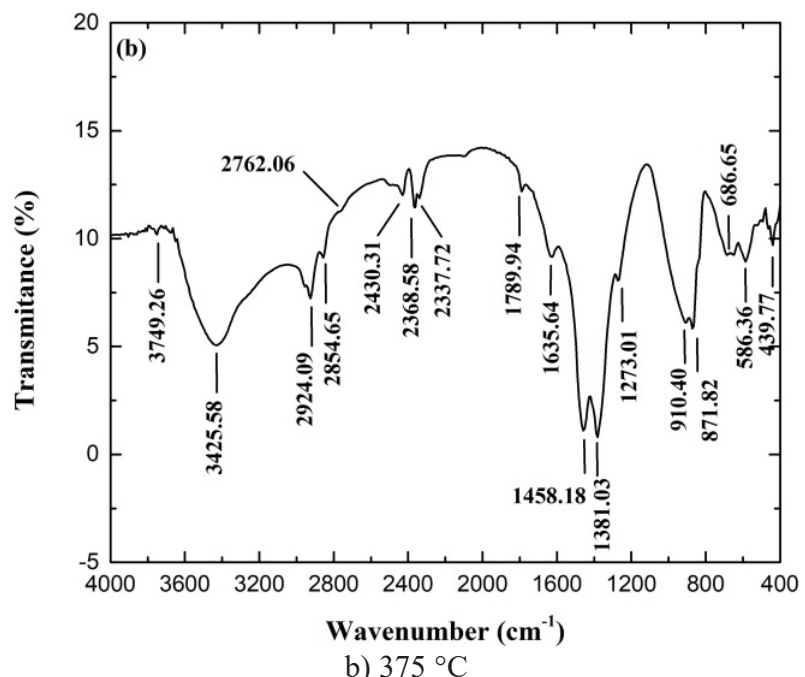

continues on next page ...

Figure 1. FTIR spectra of the samples thermally treated at different temperatures. 

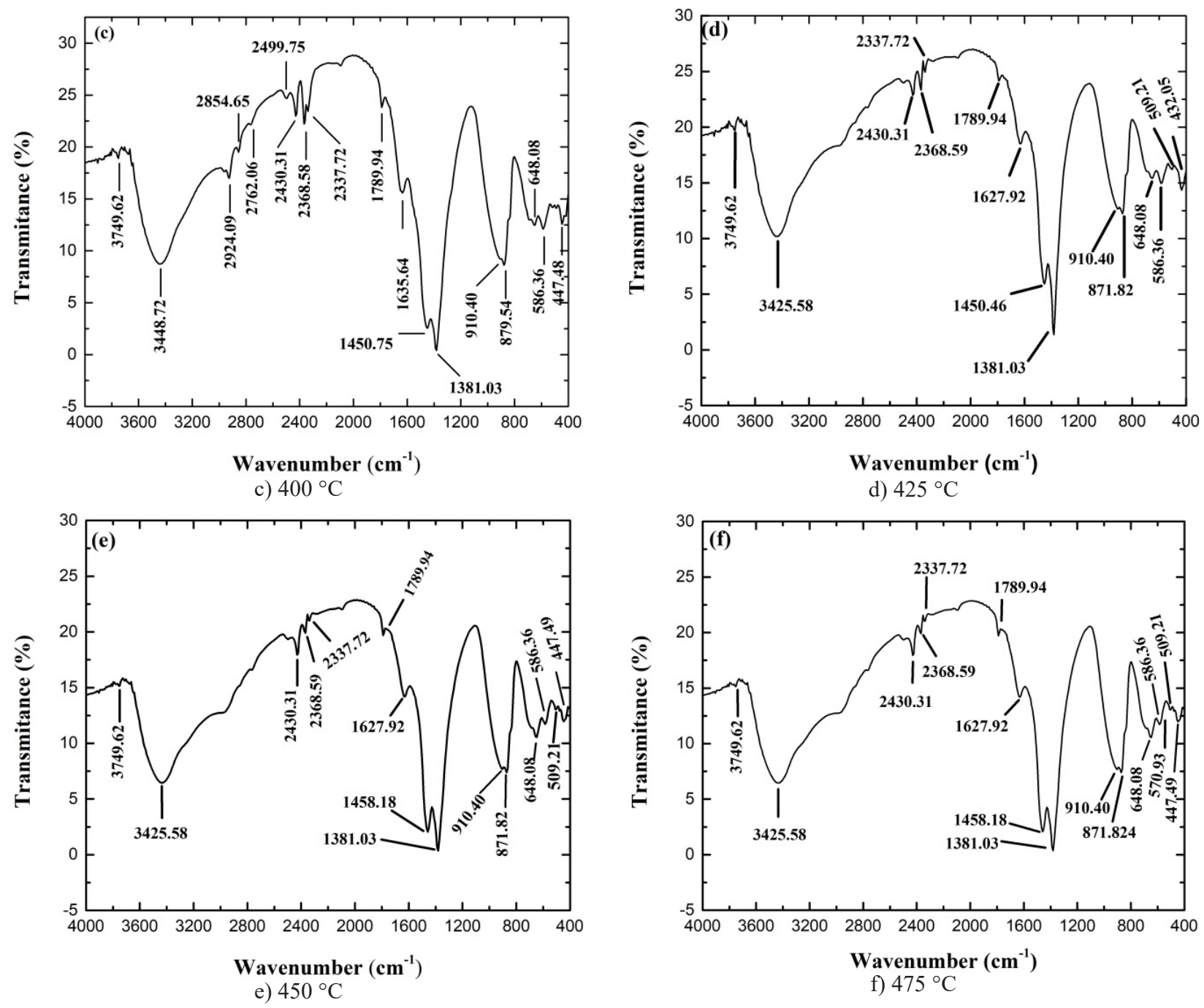

Figure 1. FTIR spectra of the samples thermally treated at different temperatures.

the existence of the $\mathrm{Na}_{2} \mathrm{FeSiO}_{4}$ phase in the samples as reported by previous studies [12]. The absorption peak in the area of wave number $455.20-432.05$ $\mathrm{cm}^{-1}$ indicates the presence of bending vibrations of the Na-O group of the $\mathrm{NaO}_{4}$ tetrahedral [33]. The absorption peak of wave number $686.65-509.21 \mathrm{~cm}^{-1}$ is related to the stretching vibration of the $\mathrm{Fe}-\mathrm{O}$ group of $\mathrm{FeO}_{4}$ tetrahedral [34-35]. The sharp absorption peak of wave number $910.40-871.82 \mathrm{~cm}^{-1}$ indicated the presence of stretching vibrations of the $\mathrm{Si}-\mathrm{O}$ group of the $\mathrm{SiO}_{4}$ tetrahedral [36]. In addition to the existence of Na-O, Fe-O, and Si-O groups, the FTIR spectra also indicate the $-\mathrm{OH}$ groups marked by the broadband at $3433.29-3425.58 \mathrm{~cm}^{-1}$ [37]. This functional group is predicted to come from the water molecules trapped in the samples. This group may also come from the silanol group ( $\mathrm{Si}-\mathrm{OH}$ ) because the existence of the group was detected at the absorption peak of $3749.62 \mathrm{~cm}^{-1}$ [3839]. In these spectra, the $\mathrm{C}-\mathrm{H}$ and $\mathrm{C}=\mathrm{O}$ groups are also identified. The $\mathrm{C}-\mathrm{H}$ group is detected in the wavenumber of $2368.59-2337.72 \mathrm{~cm}^{-1}$ and around a strong absorption peak of $1458.18-1450.46 \mathrm{~cm}^{-1}$, and the $\mathrm{C}=\mathrm{O}$ group is detected in the wavenumber of $1766.17-1789.94 \mathrm{~cm}^{-1}$. The $\mathrm{C}=\mathrm{O}$ and $\mathrm{C}-\mathrm{H}$ groups probably came from the chelating agent $\mathrm{C}_{6} \mathrm{H}_{8} \mathrm{O}_{7} \cdot \mathrm{H}_{2} \mathrm{O}$ remaining in the samples [40].

The phases in the samples were analysed using the search match method operated on the QualX software, namely by comparing the experimental diffraction data with the open crystallography database (COD), which was installed in the program. However, the COD has not yet been provided with the database of the $\mathrm{Na}_{2} \mathrm{FeSiO}_{4}$ phase. According to previous studies, the $\mathrm{Na}_{2} \mathrm{FeSiO}_{4}$ phase is an isostructure with polyanionic compounds such as $\mathrm{Na}_{2} \mathrm{ZnSiO}_{4}, \mathrm{Na}_{2} \mathrm{MnSiO}_{4}$, and $\mathrm{Na}_{2} \mathrm{CaSiO}_{4}$ [15]. Therefore, the experimental data were matched with the COD of the polyanion compound. As a result, the crystallographic data of each sample matched the database of the $\mathrm{Na}_{2} \mathrm{CaSiO}_{4}$ phase with the card number COD 00-101-0111. The diffractogram of each sample is depicted in Figure 2. The diffraction peak, which indicates the $\mathrm{Na}_{2} \mathrm{FeSiO}_{4}$ phase, is located at $2033.97^{\circ}$ as the prominent peak that characterises the phase. This pha- 


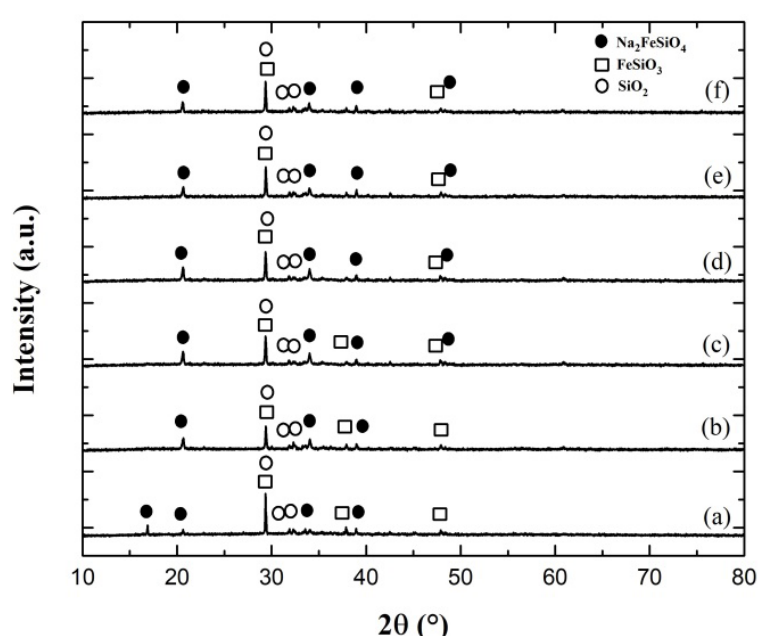

Figure 2. The XRD pattern of the samples thermally treated at different temperatures, a) $350{ }^{\circ} \mathrm{C}$, b) $375{ }^{\circ} \mathrm{C}$, c) $400{ }^{\circ} \mathrm{C}$, d) 425 ${ }^{\circ} \mathrm{C}$, e) $450{ }^{\circ} \mathrm{C}$, f) $475^{\circ} \mathrm{C}$.

se was also identified by the appearance of diffraction peaks at angles of $2 \theta 20.54^{\circ}$ and $45.05^{\circ}$, which were also associated with this phase. This analysis agrees with a previous reported study $[7,30]$. This analysis also finds the $\mathrm{FeSiO}_{3}$ phase with a dominant peak at $2 \theta 29.36^{\circ}$ and several diffraction peaks at $2 \theta 34.09^{\circ}, 37.98^{\circ}, 43.53^{\circ}$, and $47.82^{\circ}$ (COD 00-900-1627). In addition, there are also diffraction peaks related to the $\mathrm{SiO}_{2}$ phase (COD $00-900-7171)$ at $2 \theta 29.38^{\circ}, 31.90^{\circ}$, and $32.49^{\circ}$. Based on this analysis, the $\mathrm{Na}_{2} \mathrm{FeSiO}_{4}$ phase has a cubic structure with a $\mathrm{P} 213$ space group, and the $\mathrm{FeSiO}_{3}$ phase has a monoclinic structure with a P $121 / \mathrm{c} 1$ space group. Meanwhile, the $\mathrm{SiO}_{2}$ phase has a triclinic structure with a C $12 / \mathrm{C} 1$ space group. The presence of these three phases in the sample indicates the suitability of the functional group analysis, which indicates the presence of the Na-O, Fe-O, and Si-O bonds. The presence of the three phases in the sample indicates compliance with the functional group analysis, which shows the presence of the $\mathrm{Na}-\mathrm{O}, \mathrm{Fe}-\mathrm{O}$, and $\mathrm{Si}-\mathrm{O}$ groups in the sample, because the $\mathrm{Na}_{2} \mathrm{FeSiO}_{4}, \mathrm{FeSiO}_{3}$, and $\mathrm{SiO}_{2}$ phases are formed by a covalent bond from one or a combination of these groups.

The crystallographic database of each phase obtained from the qualitative analysis is then used as the input data in the refinement analysis. This analysis was performed with Rietica software by applying the Rietveld method. The output of this analysis is depicted in Figure 3, while the refinement parameters are shown in Table 1. Table 1 reveals that all the samples have $R_{\text {exp }}, R_{w}$, and $R_{p}$ values less than $11 \%$ and Goodness of Fit (GoF) values less than $1 \%$. According to previous studies, if the GoF value is less than $4 \%$ and the $R_{w p}$ is less than $25 \%$, the refinement mechanism has met the standard Rietveld method [20,41]. Thus, this analysis confirms the accuracy of the qualitative analysis, which revealed that there are $\mathrm{Na}_{2} \mathrm{FeSiO}_{4}, \mathrm{FeSiO}_{3}$, and $\mathrm{SiO}_{2}$ phases in the samples. The output of this refinement analysis also includes the weight percent (wt. \%) of each phase, as shown in Table 2. The wt. \% of each sample is

Table 1. The figure of merit from the refinement of the XRD data for the samples thermally treated at different temperatures.

\begin{tabular}{ccccc}
\hline $\begin{array}{c}\text { Temperature } \\
\left({ }^{\circ} \mathrm{C}\right)\end{array}$ & $R_{w p}$ & $R_{p}$ & $R_{\exp }$ & $\mathrm{GoF}$ \\
\hline 350 & 6.79 & 4.94 & 10.70 & 0.40 \\
375 & 6.36 & 4.78 & 9.37 & 0.46 \\
400 & 6.75 & 4.71 & 9.97 & 0.45 \\
425 & 6.22 & 4.85 & 9.00 & 0.47 \\
450 & 6.73 & 5.33 & 10.10 & 0.44 \\
475 & 6.52 & 4.80 & 9.38 & 0.48 \\
\hline
\end{tabular}

Table 2. Wt. \% from the refinement of the XRD data for the samples thermally treated at different temperatures.

\begin{tabular}{cccc}
\hline $\begin{array}{c}\text { Temperature } \\
\left({ }^{\circ} \mathrm{C}\right)\end{array}$ & $\mathrm{Na}_{2} \mathrm{FeSiO}_{4}$ & $\mathrm{FeSiO}_{3}$ & $\mathrm{SiO}_{2}$ \\
\hline 350 & 73.44 & 19.03 & 7.53 \\
375 & 73.46 & 18.94 & 7.60 \\
400 & 73.66 & 18.91 & 7.43 \\
425 & 74.08 & 19.33 & 6.59 \\
450 & 73.74 & 19.29 & 6.97 \\
475 & 74.23 & 18.76 & 7.01 \\
\hline
\end{tabular}

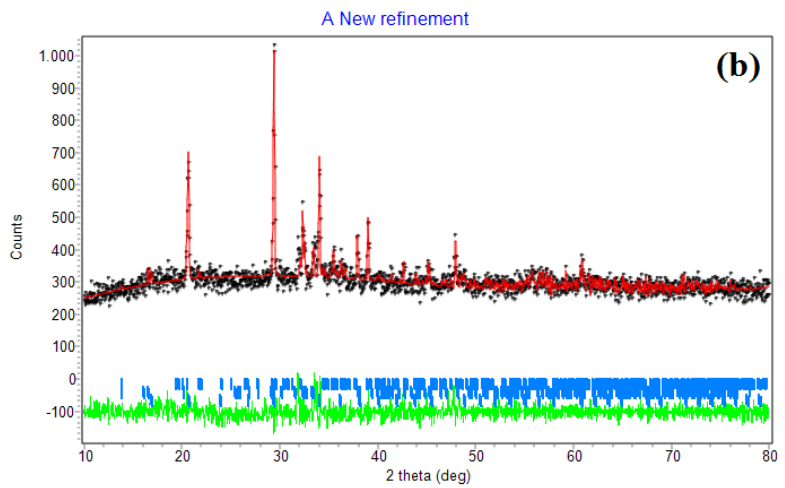

a) $375{ }^{\circ} \mathrm{C}$

Figure 3. XRD Rietveld plot for the samples thermally treated at different temperatures. The observed data are shown by the $(+)$ sign and the calculated data by a solid line.

continues on next page ... 


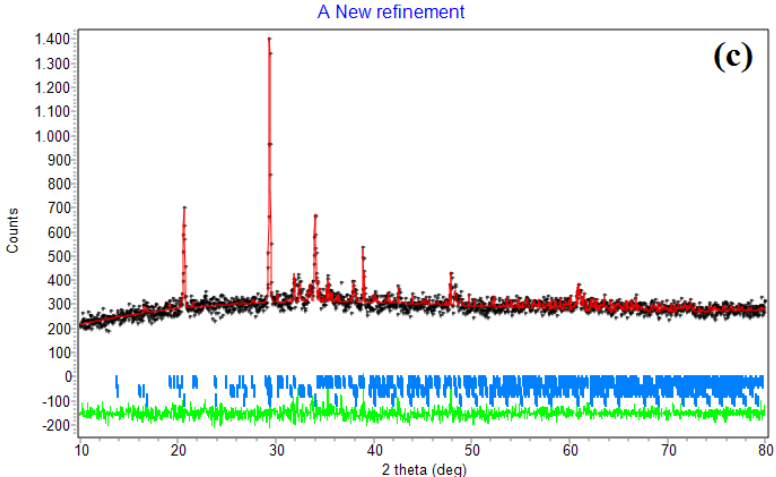

c) $400{ }^{\circ} \mathrm{C}$

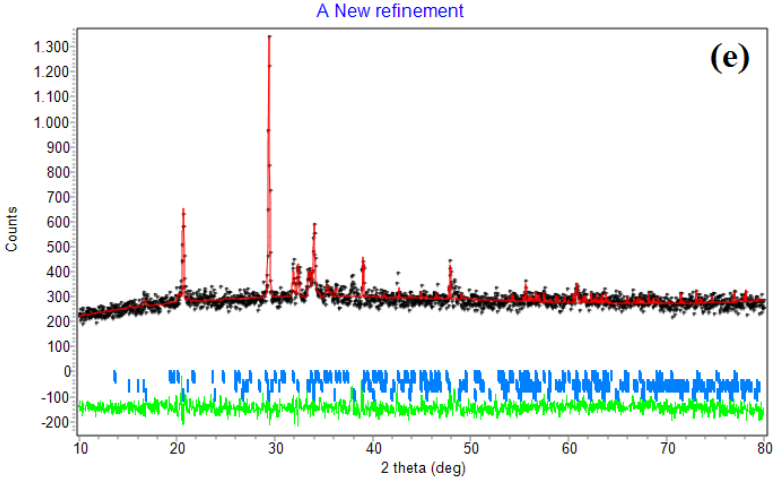

e) $450^{\circ} \mathrm{C}$

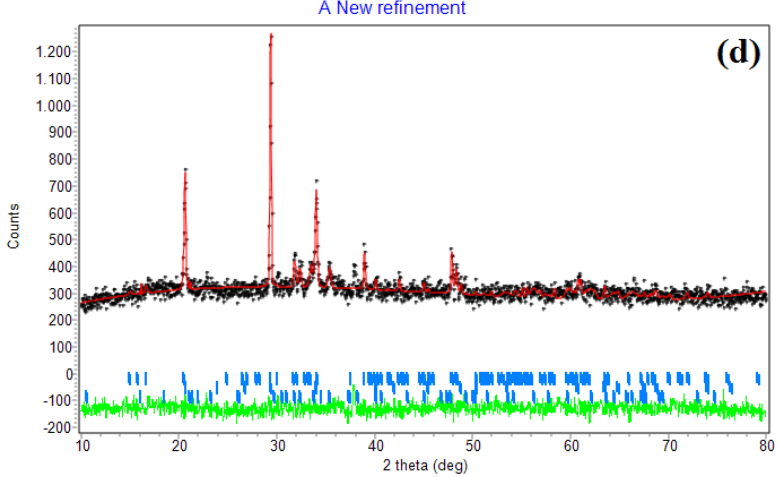

d) $425{ }^{\circ} \mathrm{C}$

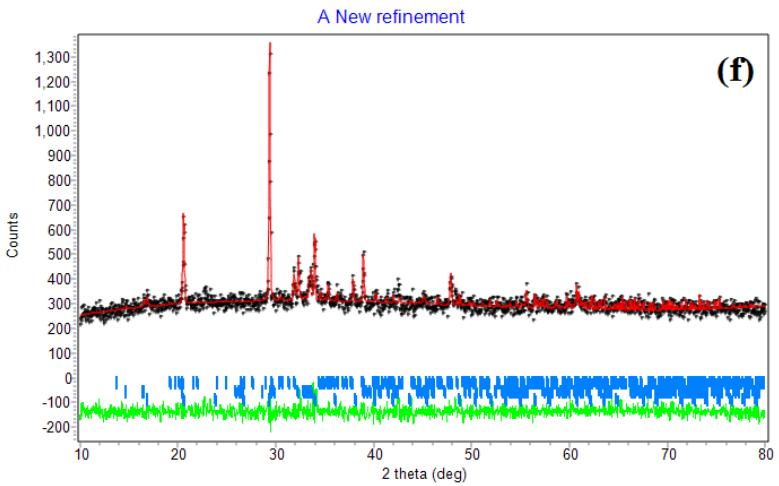

f) $475{ }^{\circ} \mathrm{C}$

Figure 3. XRD Rietveld plot for the samples thermally treated at different temperatures. The observed data are shown by the $(+)$ sign and the calculated data by a solid line.

dominated by the $\mathrm{Na}_{2} \mathrm{FeSiO}_{4}$ phase followed by $\mathrm{FeSiO}_{3}$ and $\mathrm{SiO}_{2}$. The presence of secondary phases such as $\mathrm{FeSiO}_{3}$ and $\mathrm{SiO}_{2}$ indicates that the gelation and solidstate reaction leading to the formation of a $\mathrm{Na}_{2} \mathrm{FeSiO}_{4}$ phase was not achieved because the reactants were not stoichiometrically mixed or the solid-state reaction was not kinetically achieved. However, the composition of the $\mathrm{Na}_{2} \mathrm{FeSiO}_{4}$ phase tends to increase with an increasing thermal treatment temperature. However, it decreased in the sample thermally treated at $450{ }^{\circ} \mathrm{C}$. The increase in the wt. $\%$ of the $\mathrm{Na}_{2} \mathrm{FeSiO}_{4}$ phase was followed by an increase in the unit cell volume of the $\mathrm{Na}_{2} \mathrm{FeSiO}_{4}$ phase, as shown in Table 3. The change in the wt. \% and cell volume of $\mathrm{Na}_{2} \mathrm{FeSiO}_{4}$ is related to the thermal treatment temperature and crystal growth function. Meanwhile, the wt. \% and the unit cell volume of the secondary phase tend to decrease with an increasing temperature.

The band gap values of the samples were estimated using the Kubelka-Munk equations and Tauc relation. The Tauc plot is shown in Figure 4. The estimated band gap of the samples sintered at $350{ }^{\circ} \mathrm{C}, 375^{\circ} \mathrm{C}, 400{ }^{\circ} \mathrm{C}$, $425^{\circ} \mathrm{C}, 450{ }^{\circ} \mathrm{C}$, and $475^{\circ} \mathrm{C}$ are $2.00 \mathrm{eV}, 1.99 \mathrm{eV}, 1.98 \mathrm{eV}$, $1.92 \mathrm{eV}, 1.98 \mathrm{eV}$ and $1.95 \mathrm{eV}$, respectively. This estimate agrees with previous studies that stated that the band gap of the $\mathrm{Na}_{2} \mathrm{FeSiO}_{4}$ phase ranges from 1.23 to $2.51 \mathrm{eV}$ [11]. Therefore, the band gap of the samples mainly comes from the contribution of the $\mathrm{Na}_{2} \mathrm{FeSiO}_{4}$ phase because it is the main phase, and the number reaches
Table 3. Unit cell volume from the refinement of the XRD data for the samples thermally treated at different temperatures (in units of $\AA^{3}$ )

\begin{tabular}{cccc}
\hline $\begin{array}{c}\text { Temperature } \\
\left({ }^{\circ} \mathrm{C}\right)\end{array}$ & $\mathrm{Na}_{2} \mathrm{FeSiO}_{4}$ & $\mathrm{FeSiO}_{3}$ & $\mathrm{SiO}_{2}$ \\
\hline 350 & 409.841 & 462.666 & 639.556 \\
375 & 412.661 & 460.501 & 638.606 \\
400 & 412.827 & 464.143 & 632.414 \\
425 & 417.421 & 448.285 & 477.686 \\
450 & 416.915 & 447.650 & 505.531 \\
475 & 417.040 & 435.186 & 522.446 \\
\hline
\end{tabular}

more than $73 \%$ in each sample, as shown in Table 2. Meanwhile, the secondary phase is less than $27 \%$, divided into two different phases. Thus, the secondary phase only provides a small influence to the samples' band gap. Changes in the band gap value show a close relationship with the wt. \% and the unit cell volume of the $\mathrm{Na}_{2} \mathrm{FeSiO}_{4}$ phase. The band gap value is inversely proportional to the wt. $\%$ and the unit cell volume. The unit cell volume plays a significant role in determining the band gap of the phase because changes in the unit cell volume influence the state of the band structure. The larger the unit cell volume, the higher the band gap [42]. Table 3 shows that the unit cell volume of the primary phase tends to increase with an increasing thermal treatment temperature so that the band gap value of the sample tends to decrease inversely proportional to its unit cell volume. The downward trend in the band gap 


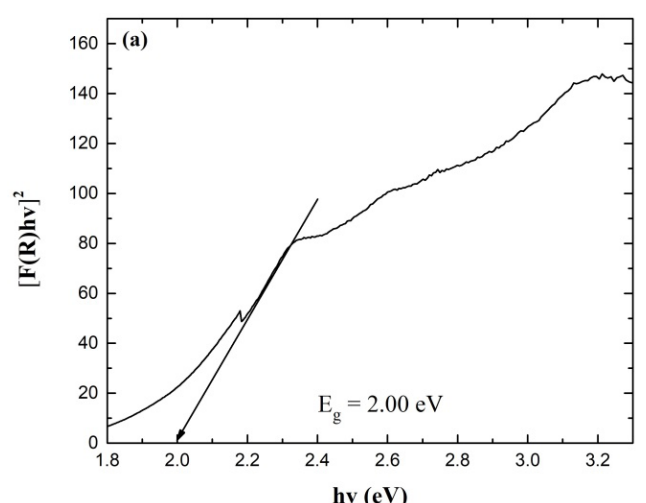

a) $350{ }^{\circ} \mathrm{C}$

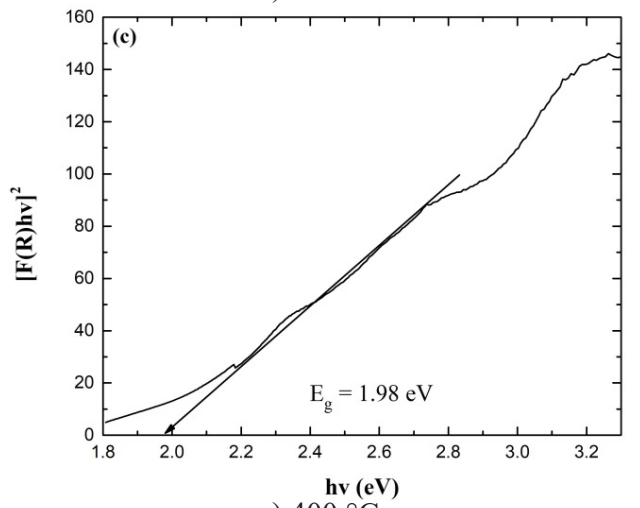

c) $400{ }^{\circ} \mathrm{C}$

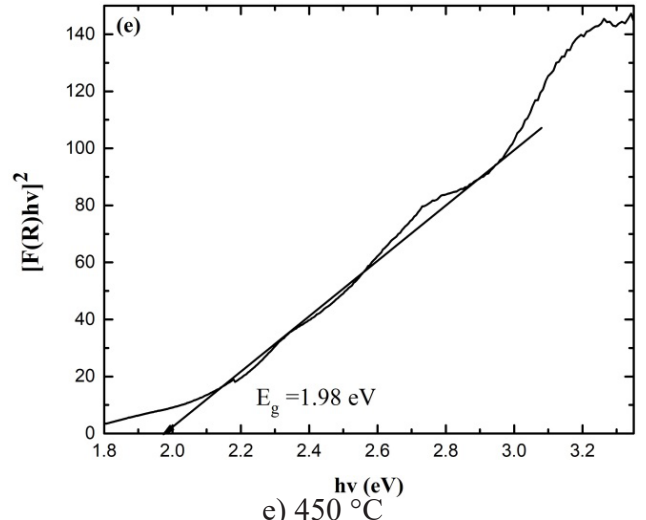

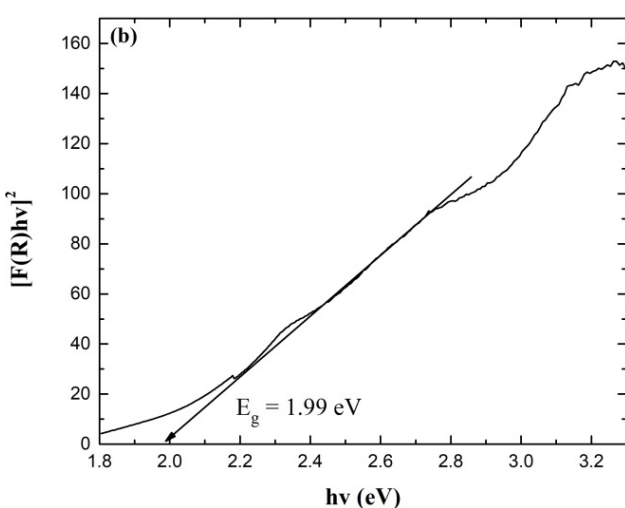

b) $375^{\circ} \mathrm{C}$

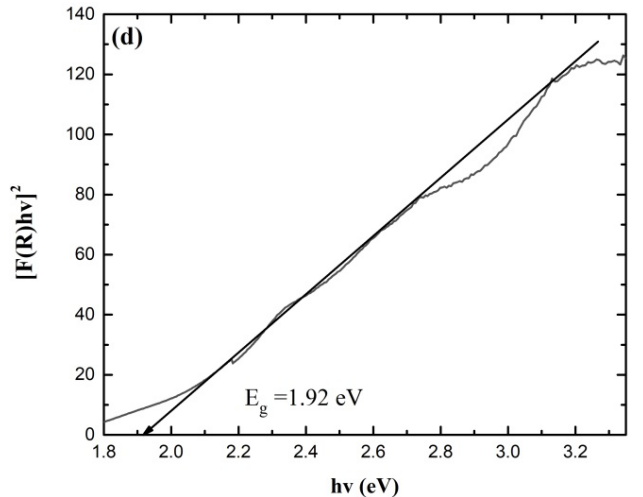

d) $425^{\circ} \mathrm{C}(\mathbf{C V}$

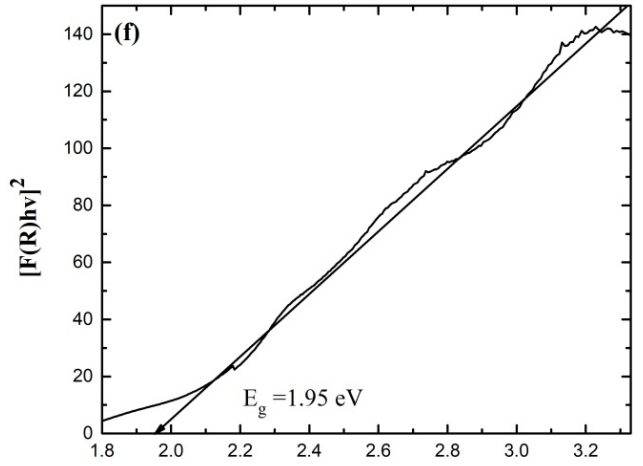

f) $475^{\circ} \mathrm{hv}(\mathrm{CV})$

Figure 4. Tauc plot of the samples thermally treated at different temperatures.

is also supported by the tendency to narrow the unit cell volume of the secondary phases as the thermal treatment temperature increases, as shown in Table 3. It causes the cell volume of samples to be dominated by unit cells of the primary phase, thereby causing changes in the band structure which triggers the band gap width to narrow.

Meanwhile, the conductivity value increases as the sintering temperature increases as depicted in Figure 5 and Table 4. All the samples have electrical conductivity in the order of $10^{-5} \mathrm{~S} \cdot \mathrm{m}^{-1}$, similar to the results of our previous study [12]. The electrical conductivity of each sample is closely related to the band gap. Samples with small band gaps allow electrons to move from the valence band to the conduction band with lower energy. Thus, the smaller band gap sample has a more excellent electrical conductivity [43]. Therefore, the electrical conductivity of the $\mathrm{Na}_{2} \mathrm{FeSiO}_{4}$ sample shows a pattern

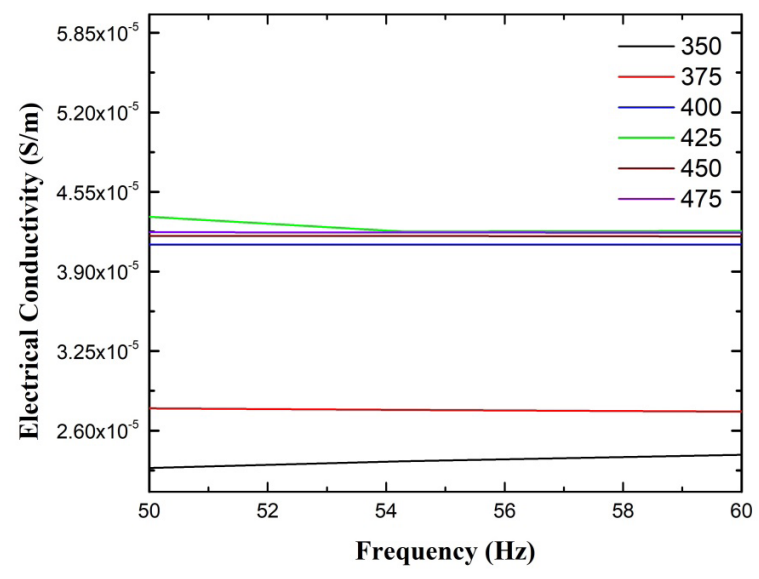

Figure 5. Electrical conductivity in a frequency of $50-60 \mathrm{~Hz}$ from the samples thermally treated at different temperatures. 
Table 4. Electrical conductivity in a frequency of $50-60 \mathrm{~Hz}$ from the samples sintered at different temperatures.

\begin{tabular}{lc}
\hline $\begin{array}{l}\text { Temperature } \\
\left({ }^{\circ} \mathrm{C}\right)\end{array}$ & $\begin{array}{c}\text { Electrical conductivity } \\
\left(\mathrm{S} \cdot \mathrm{m}^{-1}\right)\end{array}$ \\
\hline 350 & $2.35 \times 10^{-5}-2.44 \times 10^{-5}$ \\
375 & $2.74 \times 10^{-5}-2.77 \times 10^{-5}$ \\
400 & $4.12 \times 10^{-5}-4.14 \times 10^{-5}$ \\
425 & $4.35 \times 10^{-5}-4.23 \times 10^{-5}$ \\
450 & $4.19 \times 10^{-5}-4.19 \times 10^{-5}$ \\
475 & $4.22 \times 10^{-5}-4.22 \times 10^{-5}$ \\
\hline that 1S inversely proportional to the band gap.
\end{tabular}

\section{CONCLUSIONS}

This investigation succeeded in revealing the effect of the thermal treatment on the formation of the $\mathrm{Na}_{2} \mathrm{FeSiO}_{4}$ phase and the band gap and electrical conductivity. The study showed that each sample was dominated by the $\mathrm{Na}_{2} \mathrm{FeSiO}_{4}$ phase, followed by the $\mathrm{FeSiO}_{3}$ and $\mathrm{SiO}_{2}$ phases. The weight percent and unit cell volume of the $\mathrm{Na}_{2} \mathrm{FeSiO}_{4}$ phase tended to increase with an increasing thermal treatment temperature, but the band gap values showed an inverse trend to the weight percent and unit cell volumes. At the same time, the value of the electrical conductivity is proportional to the percent by weight and volume of the unit cell of the $\mathrm{Na}_{2} \mathrm{FeSiO}_{4}$ phase.

\section{Acknowledgements}

The authors would like to thank the University of Lampung, which provided the financial support in this research.

\section{REFERENCES}

1. Zhao Y., Pohl O., Bhatt A. I., Collis G. E., Mahon P. J., Rüther T., Hollenkamp A. F. (2021): A review on battery market trends, second-life reuse, and recycling. Sustainable Chemistry, 2(1), 167-205. doi: 10.3390/suschem2010011

2. Deng D. (2015): Li-ion batteries: basics, progress, and challenges. Energy Science \& Engineering, 3(5), 385418. doi: $10.1002 /$ ese 3.95

3. Ni J., Jiang Y., Bi X., Li L., Lu J. (2017): Lithium iron orthosilicate cathode: progress and perspectives. ACS Energy Letters, 2, 1771-1781. doi: 10.1021/ acsenergylett. $7 \mathrm{~b} 00452$

4. Nytén A., Abouimrane A., Armand M., Gustafsson T., Thomas J. O. (2005): Electrochemical performance of $\mathrm{Li}_{2} \mathrm{FeSiO}_{4}$ as a new Li-battery cathode material. Electrochemistry Communications, 7(2), 156-160. doi: 10.1016/j.elecom.2004.11.008

5. Liu L., Wang P., Li J., Shi G., Ma L., Zhao J., An H. (2018): Hydrothermal preparation and intrinsic transport properties of nanoscale. Solid State Ionics, 320, 353-359. doi: 10.1016/j.ssi.2018.03.025

6. Guan W., Pan B., Zhou P., Mi J., Zhang D., Xu J., Jiang Y. (2017): A high capacity, good safety and low cost $\mathrm{Na} 2 \mathrm{FeSiO} 4-$ based cathode for rechargeable sodium-ion battery. Applied Materials \& Interfaces Metals, 9(27),
22369-22377. doi: 10.1021/acsami.7b02385

7. Li S., Guo J., Ye Z., Zhao X., Wu S., Mi J. X., Wang C.Z., Gong Z., McDonal M.J., Zhu Z., Ho K.M., Yang Y. (2016): Zero-strain $\mathrm{Na} 2 \mathrm{FeSiO} 4$ as novel cathode material for sodium-ion batteries. ACS Applied Materials and Interfaces, 8(27), 17233-17238. doi: 10.1021/acsami.6b03969

8. Palomares V., Serras P., Villaluenga I., Hueso K. B., Carretero-González J., Rojo T. (2012): Na-ion batteries, recent advances and present challenges to become low cost energy storage systems. Energy and Environmental Science, 5(3), 5884-5901. doi: 10.1039/c2ee02781j

9. Yu, S, Hu J. Q., Hussain M. B., Wu S. Q., Yang Y., Zhu Z. Z. (2018): Structural stabilities and electrochemistry of $\mathrm{Na}_{2} \mathrm{FeSiO}_{4}$ polymorphs: first-principles calculations. Journal of Solid State Electrochemistry, 22(7), 2237-2245. doi: 10.1007/s10008-018-3931-1

10. Ye Z., Zhao X., Li S., Wu S., Wu P., Nguyen M. C., Guo J., Mi J., Gong Z., Zhu Z. Z., Yang Y., Wang C.Z., Ho K. M. (2016): Robust diamond-like Fe-Si network in the zerostrain $\mathrm{Na}_{\mathrm{x}} \mathrm{FeSiO}_{4}$ cathode. Electrochimica Acta, 212, 934 940. doi: 10.1016/j.electacta.2016.07.073

11. Bianchini F., Fjellvåg H., Vajeeston P. (2017): First-principles study of the structural stability and electrochemical properties of $\mathrm{Na}_{2} \mathrm{MSiO}_{4}(\mathrm{M}=\mathrm{Mn}, \mathrm{Fe}, \mathrm{Co}$ and Ni) polymorphs. Physical Chemistry Chemical Physics, 19(22), 14462-14470. doi: 10.1039/c7cp01395g

12. Riyanto A., Sembiring S., Amalia A. R., Astika A., Marjunus R. (2020): A preliminary study of phases, elemental mapping, and electrical properties on $\mathrm{Na}_{2} \mathrm{FeSiO}_{4}$ derived from rice husk silica. Journal of Physics: Conference Series, 1572, 1-9. doi: 10.1088/1742-6596/1572/1/012003

13. Guo S. P., Li J. C., Xu Q. T., Ma Z., Xue H. G. (2017): Recent achievements on polyanion-type compounds for sodium-ion batteries: Syntheses, crystal chemistry and electrochemical performance. Journal of Power Sources, 361, 285-299. doi: 10.1016/j.jpowsour.2017.07.002

14. Park M., Zhang X., Chung M., Less G. B., Sastry A. M. (2010): A review of conduction phenomena in Li-ion batteries. Journal of Power Sources, 195(24), 7904-7929. doi: 10.1016/j.jpowsour.2010.06.060.

15. KeeY., Dimov N., Staykov A., Okada S. (2016): Investigation of metastable $\mathrm{Na}_{2} \mathrm{FeSiO}_{4}$ as a cathode material for Na-ion secondary battery. Materials Chemistry and Physics, 171, 45-49. doi: 10.1016/j.matchemphys.2016.01.033

16. Wenhao G., Bin P., Peng Z., Jinxiao M., Dan Z., Jiacheng X., Yinzhu J. (2017): A high capacity, good safety and low cost $\mathrm{Na}_{2} \mathrm{FeSiO}_{4}$-based cathode for rechargeable sodium-ion battery. ACS Applied Materials \& Interfaces, 9(27), 2236922377. doi: 10.1021/acsami.7b02385

17. Kaliyappan K., Chen Z. (2018): Facile solid-state synthesis of eco-friendly sodium iron silicate with exceptional sodium storage behaviour. Electrochimica Acta, 283, 13841389. doi: 10.1016/j.electacta.2018.07.034

18. Feng Z., Tang M., Yan Z. (2018): 3D conductive CNTs anchored with $\mathrm{Na} 2 \mathrm{FeSiO} 4$ nanocrystals as a novel cathode material for electrochemical sodium storage. Ceramics International, 44(17), 22019-22022. doi: 10.1016/j. ceramint.2018.08.186

19. Bai Y., Zhang X., Tang K., Yang L., Liu H., Liu L., Zhao Q., Wang Y. Wang X. (2019): Studies on the Kinetic Behaviors of $\mathrm{Na}$ Ions Insertion/Extraction in $\mathrm{Na}_{2} \mathrm{FeSiO}_{4} / \mathrm{C}$ Cathode Material at Various Desodiation States. ACS Applied Materials \& Interfaces, 11, 31980-31990. research-article. 
doi: 10.1021/acsami.9b10029

20. Sembiring S., Simanjuntak W., Situmeang R., Riyanto A. (2016): Preparation of refractory cordierite using amorphous rice husk silica for thermal insulation purposes. Ceramics International, 42(7), 8431-8437. doi: 10.1016/j. ceramint.2016.02.062

21. Sembiring S., Simanjuntak W., Situmeang R., Riyanto A., Karo-Karo P. (2017): Effect of alumina addition on the phase transformation and crystallisation properties of refractory cordierite prepared from amorphous rice husk silica. Journal of Asian Ceramic Societies, 5(2), 186-192. doi: 10.1016/j.jascer.2017.04.005

22. Sembiring S., Simanjuntak W., Situmeang R., Riyanto A., Junaidi (2018): Structural and physical properties of refractory cordierite precursors prepared from rice husk. Ceramics - Silikaty, 62(2), 163-172. doi: 10.13168/ cs.2018.0008

23. Sembiring S., Riyanto A., Simanjuntak W., Situmeang R. (2017): Effect of $\mathrm{MgO}-\mathrm{SiO} 2$ ratio on the forsterite $\left(\mathrm{Mg}_{2} \mathrm{SiO}_{4}\right)$ precursors characteristics derived from amorphous rice husk silica. Oriental Journal of Chemistry, 33(4), 1828-1836. doi: $10.13005 / \mathrm{ojc} / 330427$

24. Sembiring S., Riyanto A., Rumiyanti L., Sembiring Z., Situmeang R. (2020): Effect of sintering temperature on the structural and physical properties of forsterite using amorphous rice husk silica as refractory precursors. Journal of the Australian Ceramic Society, 56, 433-440.

25. Riyanto A., Sembiring S., Husain S., Karimah R. S., Firdaus I. (2021): Rietveld analysis of geopolymer prepared from amorphous rice husk silica with different thermal treatment Rietveld analysis of geopolymer prepared from amorphous rice husk silica with different thermal treatment. Journal of Physics: Conference Series, 1751, 1-7. doi: 10.1088/17426596/1751/1/012070

26. Bakar R. A., Yahya R., Gan S. N. (2016): Production of High Purity Amorphous Silica from Rice Husk. Procedia Chemistry, 19(2016), 189-195. doi: 10.1016/j. proche.2016.03.092

27. Rafiee E., Shahebrahimi S., Feyzi M., Shaterzadeh M. (2012): Optimization of synthesis and characterization of nanosilica produced from rice husk (a common waste material). International Nano Letters, 2, 1-8. doi: 10.1186/2228-5326-2-29

28. Hassan A. F., Abdelghny A. M., Elhadidy H., Youssef A. M. (2014): Synthesis and characterization of high surface area nanosilica from rice husk ash by surfactant-free solgel method. Journal of Sol-Gel Science and Technology, 69, 465-472. doi: 10.1007/s10971-013-3245-9

29. Saceda J. F., Leon R. L. De. (2011): Properties of silica from rice husk and rice husk ash and their utilization for zeolite y synthesis. Quimica Nova, 34(8), 1394-1397. doi: 10.1590/S0100-40422011000800018

30. Ali B., Ur-Rehman A., Ghafoor F., Shahzad M. I., Shah S. K., Abbas S. M. (2018): Interconnected mesoporous $\mathrm{Na}_{2} \mathrm{FeSiO}_{4}$ nanospheres supported on carbon nanotubes as a highly stable and efficient cathode material for sodiumion battery. Journal of Power Sources, 396, 467-475. doi: 10.1016/j.jpowsour.2018.06.049

31. Bai Y., Zhang X., Wang X., Luo Z., Chen G. (2019): Preparation and performances of novel $\mathrm{Na}_{2} \mathrm{FeSiO}_{4} / \mathrm{C}$ composite with more stable polymorph as cathode material of sodium-ion batteries. Journal of Power Sources, 430(May), 120-129. doi: 10.1016/j.jpowsour.2019.05.015
32. Altomare A., Cuocci C., Giacovazzo C. (2008): QUALX : A computer program for qualitative analysis using powder diffraction data. Journal of Applied Crystallography, 41, 815-817. doi: 10.1107/S0021889808016956

33. Rangasamy V. S., Thayumanasundaram S., Locquet J. (2018): Solvothermal synthesis and electrochemical properties of $\mathrm{Na}_{2} \mathrm{CoSiO}_{4}$ and $\mathrm{Na}_{2} \mathrm{CoSiO}_{4} /$ carbon nanotube cathode materials for sodium-ion batteries. Electrochimica Acta, 276(June 2018), 102-110. doi: 10.1016/j. electacta.2018.04.166

34. Karamipour S., Sadjadi M. S., Farhadyar N. (2015): Fabrication and spectroscopic studies of folic acidconjugated $\mathrm{Fe}_{3} \mathrm{O}_{4} @$ @u core-shell for targeted drug delivery application. Spectrochimica Acta Part A: Molecular and Biomolecular Spectroscopy, 148, 146-155. doi: 10.1016/j. saa.2015.03.078

35. Jain R., Luthra V., Arora M., Gokhale S. (2018): Infrared spectroscopic study of magnetic behavior of dysprosium doped magnetite nanoparticles. Journal of Superconductivity and Novel Magnetism, 32(2019), 325-333. doi: 10.1007/ s10948-018-4717-5

36. Ghaffari A., Behzad M. (2018): Facile synthesis of layered sodium disilicates as efficient and recoverable nanocatalysts for biodiesel production from rapeseed oil. Advanced Powder Technology, 29(5), 1265-1271. doi: 10.1016/j. apt.2018.02.019

37. Jiang X., Li S., Xiang G., Li Q., Fan L., He L., Gu K. (2016): Determination of the acid values of edible oils via FTIR spectroscopy based on the $\mathrm{O}-\mathrm{H}$ stretching band. Food Chemistry, 212(2016), 585-589. doi: 10.1016/j. foodchem.2016.06.035

38. Sheykhan M., Yahyazadeh A., Ramezani L. (2017): A novel cooperative Lewis acid / Brønsted base catalyst $\mathrm{Fe}_{3} \mathrm{O}_{4} @ \mathrm{SiO}_{2}$-APTMS-Fe(OH $)_{2}$ : An efficient catalyst for the Biginelli reaction. Molecular Catalysis, 435(2017), 166-173. doi: 10.1016/j.mcat.2017.03.032

39. Mahadevan T.S., Du J. (2018): Evaluating water reactivity at silica surfaces using reactive potentials. The Journal of Physical Chemistry, 122, 18. doi: 10.1021/acs. jpcc.7b12653APSa

40. Sivaraj P., Nalini B., Abhilash K. P., Lakshmi D., Selvin P. C., Balraju P. (2018): Study on the influences of calcination temperature on structure and its electrochemical performance of $\mathrm{Li}_{2} \mathrm{FeSiO}_{4} / \mathrm{C}$ nanocathode for Lithium Ion Batteries. Journal of Alloys and Compounds, 740, 11161124. doi: 10.1016/j.jallcom.2018.01.051

41. Kisi E. H. (1994): Rietveld analysis of powder diffraction patterns. Materials Forum, 18, 135-155.

42. Malevu T. D., Ocaya R. O. (2015): Effect of annealing temperature on structural, morphology and optical properties of $\mathrm{ZnO}$ nano-needles prepared by Zinc-air cell system method. International Journal of Electrochemical Science, 10, 1752-1761.

43. Sawickia B., Tomaszewicz E., Piątkowska M., Groń T., Duda H., Górny K. (2016): Correlation between the band-gap energy and the electrical conductivity in correlation between the band-gap energy and the electrical conductivity in $\mathrm{MPr}_{2} \mathrm{~W}_{2} \mathrm{O}_{10}$ Tungstates (where $\mathrm{M}=\mathrm{Cd}, \mathrm{Co}$, Mn). Acta Physica Polineca A, 129, 94-96. doi: 10.12693/ APhysPolA.129.A-94 